\title{
(Im)mobilities and migration in the work of César Mba Abogo and Donato Ndongo-Bidyogo
}

\section{Julia Borst}

Julia Borst is a postdoctoral researcher at the University of Bremen. Her research, funded by the German Research Foundation (DFG), focuses on the Black diaspora in Spain and Afro-Spanish literary and cultural production.

Email: borst@uni-bremen.de

ORCID: https://orcid.org/0000-0002-4068-0851

DOI 10.17159/2309-9070/tvl.v.56i1.6277

\section{(Im)mobilities and migration in the work of César Mba Abogo and Donato Ndongo- Bidyogo}

Many literary texts written by authors of African origin in the Spanish language engage with the experience of migration and of living in a European society that marginalizes and homogenizes migrants as the 'African Other.' Rather than reproduce stereotypical images of African migrants, these texts challenge a biased debate on migration to Europe, offering an alternative vision of a complex phenomenon. In these texts, migrants are individuals whose mobility is restricted because they are subjected to processes of Othering, which confine them to the margins of Spanish society, raising issues of mobility in/justice and forced im/mobilities related to hegemonic power relations, coloniality, and race. Privileging the perspective of African migrant subjects in creating new imaginaries of migration to Europe, this article examines the mobilities paradigm in the context of transnational migration in a postcolonial era and discusses the potential of literary texts to unsilence 'immobile voices.' Through this lens, I offer readings of César Mba Abogo's El Porteador de Marlow: Canción negra sin color (2007) and Donato Ndongo-Bidyogo's El Metro (2007), grounding my scholarship in Equatoguinean literature and contemporary hispanophone African literature. Keywords: César Mba Abogo, Donato NdongoBidyogo, African migration, Equatorial Guinea, mobility studies, African literature in Spanish.

\section{Introduction}

In 2016, I visited Koyo Kouoh's "Streamlines: Oceans, Global Trade and Migration" in Hamburg, Germany. Bringing together fifteen projects by artists from different countries, the exhibition focuses on the ocean as both a space of global mobility of people, as well as products, in the past and present, and a space where social, political, and economic inequalities become manifest (Luckow). Transnational and transoceanic migratory flows are one of the main topics addressed in the exhibition. For instance, Bouchra Khalili's "The Constellations" (2011) consists of blue maps that translate migrants' journeys into abstract, nomadic travel routes; routes that, resembling the constellation of stars, contest normative geography and erase boundaries (Khalili). Kader Attia's "La Mer Morte" (2015) (The Dead Sea), an installation of ap- 
proximately 300 pieces of used clothing on a floor, as if washed up on a shore (Attia), evokes the many victims that have died in the Mediterranean. The work speaks to the 'European refugee crisis,' a phenomenon that was at its peak at the time of the exhibition. These artist interventions reflect one of the exhibition's main aims: to draw a critical image of migrant movements and mobilities, emphasizing the complexity and precariousness of their stories, as well as the geopolitical entanglements of the causes and effects of transnational migration.

Building on and in solidarity with this critical focus, I offer readings of César Mba Abogo's El Porteador de Marlow: Canción negra sin color (Marlow's Boy: Black Song Without Color) and Donato Ndongo-Bidyogo's El Metro (The Metro), situating these texts (both published in 2007) as narratives of migration and mobilities in Equatoguinean literature and contemporary hispanophone African literature. These texts overhaul current stereotypical images of African migrants, which characterize an ongoing debate in Western societies and media. Rather than reproducing stereotypes, Mba Abogo's and Ndongo-Bidyogo's respective works write back to a biased vision of African and Afrodescendant people by raising issues of mobility in/justice, of forced $\mathrm{im} /$ mobilities, and their relationship with hegemonic power in a modern/colonial world. Examining the mobilities paradigm in the context of transnational migration in a postcolonial era, I discuss the potential of literary texts in unsilencing 'immobile voices,' voices that create new imaginaries of migration to Europe.

Many texts (testimonial and fictional) written by authors of African origin in the Spanish language represent migrants as people whose mobility is restricted because they are subjected to processes of othering which confines them to the margins of Spanish society. In this vein, the short story and poem collection, El Porteador de Marlow, clearly references Joseph Conrad's Heart of Darkness (1899), substituting the Eurocentric perspective of Joseph Conrad's narrator with an African migrants' view, unveiling hitherto silenced narratives of mobility and immobility.

Similarly, El Metro centers the topic of undocumented migration through the life story of its protagonist, Lambert Obama Ondo, echoing the author's short stories "El Sueño" (1973) (The Dream) and "La Travesía" (1977) (The Crossing) (for an overview of Ndongo-Bidyogo's writing, see Otabela Mewolo, Literatura; Ugarte; Koné). While in his first two novels_Tinieblas de tu memoria negra (1987) (Shadows of your Black Memory) and Los poderes de la tempestad (1997) (The Powers of the Storm) - the author primarily focuses on his native Equatorial Guinea's history, colonial and dictatorial violence, questions of exile and return as well as on the situatedness of African societies between tradition and modernity, El Metro explicitly approaches the topic of undocumented migration through the life story of the protagonist Lambert Obama Ondo.

In his book Africans in Europe, based on the experience of Equatoguinean exiles and emigrants in Spain, Michael Ugarte coins the neologism "eximile" to capture 
the complexity of people's journeys and 'decisions' to leave. He points out $(2,8)$ that a dichotomous distinction between exile as an (politically motivated) involuntary condition and emigration as a (economically motivated) chosen condition does not seize postcolonial realities in which both concepts, instead, tend to be overlapping. The mobilities paradigm allows us to precisely grasp and substantiate these complex entanglements of voluntary and involuntary movements or fixities. This article firstly elucidates a few facts about the mobilities paradigm and its significance with respect to transnational migration in a postcolonial context before offering a reading of migrants' im/mobilities in Mba Abogo's and Ndongo-Bidyogo's texts.

\section{$\mathrm{Im} /$ mobilities in times of transnational movements}

After the turn of the millennium, mobility has become a prominent paradigm in social sciences (Ohnmacht, et al. 10), one that centers the movements of people, ideas, objects, and information, as well as the mobility systems that shape our daily social life and relations (Urry 17). As John Urry (3) says, "[I]t sometimes seems as if all the world is on the move." And yet, the so-called 'mobility turn' is not only about being more mobile in an age of global movements and technological innovations. It also takes into account the ambiguity of the concept: "issues of movement and non-movement, of forced movement and of chosen fixity" (Ohnmacht, et al. 11; Urry 17). Or, as Mimi Sheller puts it in an interview, the issue of "mobility justice" as a category refers to "the power differentials that come into play $[\ldots]$ and the different affordances that different people are able to make use of, or appropriate, in becoming mobile or not" (Ferry and Sheller n. p.). In this context, some studies introduce the concept of 'motility' that refers to mobility or network capital (Urry 38) and the "capacities, competencies and choices" (Sheller 49) to (not) move; that is the range of possible mobilities or the decision of which options one realizes and which not (Sheller 49; Ohnmacht, et al. 12).

This ambiguity becomes all the more important if we think about mobility in a post/colonial context of global migration and thus discuss subaltern mobilities on a South-North axis (Fortier; Sheller 49; Urry 8). For if we consider the inconsistencies of globalization itself-having led to a free flow of goods, capital, information, and so on but not necessarily of people (Pécoud and Guchteneire 13)—it becomes evident that freedom of movement still is a privilege. As Urry (51) argues, movement and, in particular, unforced movement and the option to stay, "is power." Yet, because of precarious situations in countries of origin, migrants from the global south often cannot choose to stay. Even after leaving their countries of origin, their movements might be restricted, the result of border regimes that seek to deny access to those who are ascribed racialized identities and/or to limited social mobility within host societies (Seiler 101; Urry 36). As Hannah Cross elaborates (119-20), the migration regimes of European Union countries such as Spain are highly ambivalent and 'selective;' they 
appreciate undocumented migrants as a cheap labor force but, at the same time, confine mobility. For example, undocumented migrants are "restricted to unwanted, unskilled work" (115), regardless of training or education. Furthermore, legislation contributes to the systematic criminalization of migrants, reinforcing national and extranational imaginaries of dangerous trespassers that are perceived as a threat to host societies (Kunz and Leinonen 155).

Keeping in mind these hegemonic power relations in a modern/colonial world, recent studies argue that 'mobility capital' is unequally distributed on both national and global levels (Cross 10; Nicholson and Sheller 3; Ohnmacht, et al. 13-5). However, while inequalities depend on wealth, prestige, and economic power, constructed categories of difference, such as gender, sexuality, age, dis/ability, and race, overdetermine material realities. Thus, to understand the (non)movements of migrants from Africa, and the global south in general, we have to consider the intersections of mobility and race that impose particular restrictions on (access to) mobility. Race, as Cotten Seiler (98) explains, "has historically functioned and continues to function as an inhibitor or enabler of a given subject's spatial (and, consequently, socioeconomic) mobility." Coloniality has consequently turned and turns migrants from the global south into racialized bodies whose "whiteness (or proximity to it)" (98) determines their power to (not) move (Seiler 98; Urry 48, 52).

Through this lens, literary and mobility studies can engage in a productive conversation. Capable of drafting alternative images and imaginaries of migration, literary texts have the potential to unsilence voices that, due to hierarchical knowledge regimes, are systematically immobilized. Such imaginaries can challenge prevailing Eurocentric discourses that, according to Anne-Marie Fortier (69; emphasis mine), depicts a "movement of large numbers of nameless bodies [...] [that] objectifies migrants, with little specificities about their decisions, the conditions of migration, etc." And thus, in accordance with a "colonialist logic of the past," "perpetuat[es] the myth of uniformity that defines" these migrants (Montuori 45, 63).

\section{César Mba Abogo's El Porteador de Marlow: canción negra sin color}

In El Porteador de Marlow, Mba Abogo presents a heterogeneous picture of African migration to Europe, illuminating the phenomenon in its ambiguity. Consisting of more than 50 short narratives and lyrical texts, the text evokes a collective of perspectives that represent individual stories, de-anonymizing migration. At the same time, this multitude of texts sheds light on different aspects of the desire for and the experience of migration. It is this polyphonic structure that unveils the phenomenon of migration in all its complexity and contextualizes the migratory flows arriving in Europe into a wider context (Borst 95). However, although Mba Abogo's texts centre on movement, a close reading demonstrates how the subjects' respective and collective mobilities are continuously challenged and constricted. 
Many of the narratives in El Porteador de Marlow describe a strong desire to leave postcolonial African realities, often characterized by precarious living conditions, imminent threats of violence, and an overall lack of future prospects (Berástegui Wood 97; López Rodríguez 90). They describe migration not as a voluntary decision but as a necessity, challenging prejudiced narratives that imagine African migrants as manipulative, driven by selfish desires to profit from 'European generosity.' In "El país en el que lo redondo es cuadrado y los peces vuelan" (The Country in which the Circular is Square and where Fishes Fly), Europe as a promised land is demystified, for the protagonist, Rey, soon realizes that, by accepting his aunt's invitation to follow her to Europe, he is pursuing a utopian dream:

Sus sueños serían derribados en Europa, uno a uno serían descargados a la realidad como puras frustraciones.

His dreams would be demolished in Europe; one by one, they would be discharged into reality like sheer frustrations. (Mba Abogo 34) ${ }^{2}$

The protagonist fears not only leaving behind his loved ones but also losing his identity as a self-determined subject. He worries that "[e]n Europa no sólo sería negro, sería también africano" (in Europe he would not only be Black, he would also be African) (34). Rey acknowledges the epistemological meanings of "negro" and "africano" in Europe, how the white gaze dehumanizes black subjects, marking black bodies as migrants and refugees. Despite this knowledge, despite sueños derribados (demolished dreams), he lacks the option of not moving_- "No le quedaba más remedio, tenía que irse" (He had no other option but to leave) (35).

El Porteador de Marlow also centers experiences of involuntary fixity, resulting from prevented and interrupted movements, as well as unattainability. Accordingly, many texts describe the necessity of escaping a situation of hopelessness as an option that is not to be taken for granted. In "La rubia y el Porsche" (The Blonde and the Porsche) - a story about the illusions and the disillusionment of a group of adolescents who, having turned into "refugiados mentales" (16), keep dreaming of a life elsewhere-mobility is shown as a privilege not accessible to everyone:

Otros apenas pudieron alejarse unos centímetros, se quedaron atrapados en la banalidad, ahogándose en sufrimientos insustanciales, expuestos al hambre, a la enfermedad, despedazados por el grito irreverente que les golpeaba desde dentro.

Others could hardly move away some centimeters, they were trapped in the banality, drowning themselves in insubstantial sufferings, exposed to hunger, to disease, torn to shreds by the irreverent cry that was hitting them from deep inside. (16)

The anonymous characters described are as immobilized as their life stories, excluded 
from a discussion of migration to Europe.

"En algún lugar bajo el Atlántico" (Somewhere Below the Atlantic), a title that unmistakably alludes to the dangerous journey that countless migrants from Africa venture through in order to reach European soil, echoes the deaths of enslaved Africans who died during the Middle Passage, resituating migration (Borst 43). In Mba Abogo's text, deceased African migrants are given a voice through which they tell their stories. The drowned, first-person narrator retrospectively explains that he dreamt of offering a better life to his family, who had stayed behind. Simultaneously, his individual dream is multiplied by the narrator's evocation of all the other "muchos párpados [que se cerraban] aqui abajo" (many eyelids shut down here) (59). That these victims, suffering from precarious mobilities, have neither a locally fixed tomb nor a place where their stories are to be told, is emblematized in the title of another text in the collection entitled "Cenotafio" (36). A cenotaph is an empty tomb for someone who is buried elsewhere. This title can be read as a reminder that we need to create an archive for the memory of those whose lives are lost on their journey to Europe. Literature can provide this archive.

Finally, Mba Abogo's writing shows that movements across physical borders lead, again, to an immobility that is strongly connected to the African migrant's position as the 'Black Other,' a condition that the book's documented migrants share with the undocumented characters (Berástegui Wood 98). In the story, "What a wonderful world," it is the white gaze that establishes alterity and creates blackness as a category of non-belonging. The title, in English, further emphasizes the dark irony between Europe as paradise and the lived experience of black life in Europe, which the author represents as one of solitude and exclusion:

Como siempre, la respuesta a tantas miradas malévolas estaba en el tono de su piel. Inmigración, inseguridad ciudadana, caníbales, ola de calor africano, etc.

Like always, the answer to so many malevolent looks was in the color of his skin. Immigration, citizen insecurity, cannibals, African heat wave, etc. (Mba Abogo 58)

The protagonist's position as a social outsider is emphasized when Nguema is compared to a white young man sleeping on a bench next to him who, despite being drunk and having vomit on his face, is spared society's discriminating gaze. As the text acknowledges, this man is "sangre de su sangre y carne de su carne" (blood of their blood, flesh of their flesh) while Nguema, being one of "Los Condenados de la Tierra" (The Condemned of the Earth) (55), is perceived as a racialized body and therefore denied social affiliation.

Likewise, the short story, "Me han hecho la vida más cansada y pesada" (They Made My Life More Tiresome and More Tedious), offers insight into undocumented migrants and their social immobility within Europe. The protagonist, Héctor, is 
confronted with a double position of exclusion, as undocumented migrant and as African. He is 'outside,' cut off by the "feroz alambrada de la ilegalidad" (fierce wire fence of illegality) (46). In the reader's imagination, this vivid metaphor invokes images of the Spanish border fences of Ceuta and Melilla, symbols of Europe's tendency to seal off its borders. Mba Abogo deftly connects this physical border crossing with the insurmountable symbolic border that exists in people's minds. Perceived as the 'Black Other,' Héctor fulfills a predetermined social role shaped according to racist perceptions of black migrants from Africa:

Él era el negro y se había creado el trabajo en negro para los negros. Se hizo pasar por analfabeto, se ofreció para trabajar durante un periodo de prueba sin cobrar [...]

He was the Black and black labour had been made for Blacks. He managed to pass for an illiterate; he offered to work for a trial period with no earnings [...] (Mba Abogo 46)

El Porteador de Marlow illustrates a migrant experience of making oneself invisible in order to survive, to make a living; it is a way of being that demands voicelessness. In the final scene of "Me han hecho la vida más cansada y pesada," Nguema wants to call his mother to tell her about his sorrows but does not have the money to make a phone call. There is nothing left for him but to pick up the receiver and voice his despair into the void (47), a metaphor that vividly alludes to all the lost and unheard words about the coloniality of migration, words that can be symbolically intercepted and immortalized through literature.

\section{Donato Ndongo-Bidyogo's El Metro}

In contrast to Mba Abogo's collective of perspectives, Ndongo-Bidyogo's novel El Metro focuses on one main character, Lambert Obama Ondo. In response to the dangerous political and the precarious economic situation in his native Cameroon, he traverses a continually interrupted and dangerous journey until he reaches Spain. As scholars such as Ugarte or Mahan Ellison state in their analyses of the novel, a crucial accomplishment of the narrative lies in the fact that it triggers a change of perspective with regard to Spain's rather "monological" (Ugarte 78) debate about immigration, tackling the phenomenon from the migrant's point of view (Ellison 163; Ugarte 77). Thus, as Ellison (163) states, its "representation of the African immigrant humanizes what is so often caricatured stereotype in popular discourse."

The text retraces the protagonist's life story from his birth to his adulthood and his premature death. Of the novel's nineteen chapters, twelve are set in Cameroon, two describe the protagonist's journey from Cameroon via Senegal to the Canary Islands, and five chapters portray his life on the Canary Islands and continental Spain (Ellison 164; Mewolo and Abena 143). At first sight, migration might seem like one stage in Lambert's life. However, as the narration unfolds it becomes clear that 
the actual event of transnational border-crossing is the climax of a whole series of protagonist movements that are initiated by diverse situations of plight and distress (Arbeláez 1043).

Initially, archaic traditions and the elders' disapproval of the main character's relationship to a young woman, Anne Mengue, make him leave his native village for the capital Yaoundé. Then, economic hardship and arbitrary political violence in postcolonial Cameroon force him to migrate, first to the port city of Douala and then to hide as an undocumented migrant in a container ship that is supposed to take him to Europe. However, the protagonist is intercepted and ends up in Senegal, where he leads an undocumented life and is imprisoned for several months. Finally, Lambert Obama Ondo succeeds in getting a faked passport and boarding a plane to Morocco, from where smugglers take him to the territory of the Western Sahara. From there, he takes a small boat and reaches the Canary Islands as one of the few passengers who survive a tragedy at sea. After being stuck there for a while, bureaucratic coincidence results in the protagonist finally being sent off to mainland Spain. Moving back and forth between Murcia and Madrid, desperately trying to make a living in clandestineness, in the end the protagonist finds a violent death in Madrid, where he is murdered by a group of neo-Nazis. As we can see, the reasons for Obama Ondo's movements are multiple; they reach from archaic traditions and economic hardship to arbitrary political violence in postcolonial African societies and the precariousness of an undocumented life.

These continuous movements exemplify what Cross (8) refers to when she describes migration from Western African countries as often "unorganized journeys," for their frequently "stepwise migration [...] is characterized by a contradictory mixture of coercion, compulsion and repression combined with choice, opportunity and mobility." Moreover, she confirms a central question is what "enables" (11) migrants to effectively leave, for " $[t]$ he expansion of possibilities [...] lends itself not to a borderless world but, instead, to one with an unprecedented number of checkpoints and frontiers" (131). Likewise, Lambert does not freely choose when to leave and where to go. Rather, his mobility is described as overdetermined by external political, economic, social, and cultural constraints. Contrary to stereotypical perceptions of emigration that assume that African migrants choose to leave to improve their lives, Ndongo-Bidyogo's novel shows his readers that migrant subjects are forced to move in order to survive, as Ugarte argues in his reading of the text $(80,82)$. In many cases, Lambert seems to be moved like a pawn by those in power-a corrupt African leader who depletes the country's economy, human traffickers who arbitrarily schedule the protagonist's movements through the African continent, or European businessmen for whom African laborers are merely disposable commodities that can easily be replaced. The novel gives us a sweeping critique of actors that represent different systems of oppression and exploitation by constraining freedom of choice and movement. 
By emphasizing the life stories that precede Lambert's departure to Europe, as well as the entangled histories of Africa and Europe, the author calls on his readers to take up a more complex perspective on transnational migration. He reminds us to think critically about the causes, and not only the effects, of transnational migration. He challenges us to consider Europe's responsibility for a colonial legacy that becomes manifest in neocolonialist politics, particularly in the current oppression of African citizens by African elites who succeed(ed) European colonizers in positions of hegemonic power (Gorroño; Ndongo-Bidyogo, El Metro 192, 199; Ugarte 82).

Having a closer look at the novel's structure, the experience of migrating to Spain frames El Metro. Anticipating Lambert's life as an undocumented migrant in Spain, a life that finds a violent end in the final chapter, the novel is a retrospective that chronologically traces the protagonist's journey to Spain. One can read this circular structure as an allusion to the inevitability of the protagonist's fate, one that emphasizes the fact that the protagonist is not free to choose when, where, or how to move. For instance, Ndongo-Bidyogo illustrates this immobility rather vividly:

La mayoría de sus descubrimientos en ese lado del mundo habitado por los blancos eran inaccesibles para él, y [...] reconocía que, por más selvas, desiertos y mares que hubiese atravesado, jamás llegaría a disfrutar de tanto portento como a diario contemplaban atónitos sus ojos luminosos, intensamente negros.

The majority of his discoveries in that side of the world inhabited by white people were inaccessible to him and [...] he recognized that, no matter how many forests, deserts and oceans he could have crossed, he would never get to enjoy all these marvels that his bright, intensely black eyes contemplated and astonished every day. (NdongoBidyogo, El Metro 14)

Both framing chapters, the first and the last, are set in the Madrilenian Metro, a highly symbolical place and the novel's eponym. Highly symbolic, but just as ambivalent, it is described as a symbol for technological innovations and a progressive society-one that, according to the novel, could serve as a role model for postcolonial African leaders-as a space of mobility and passage that creates a homogeneous mass of commuters. However, the metro also constitutes a space of solitude and despair; it is where Lambert realizes that he does not, and cannot, participate in this space (Arbeláez 1050; Ndongo-Bidyogo, El Metro 284-90). Here the role of undocumented migrants is emblematized by a meaningful spatial metaphor. While Spaniards move through the underground corridors of the metro station, as a vendor of pirate copies, the protagonist maintains a static position in the middle of the flow of metro users. This image portrays Lambert as excluded and (socially) immobile (Ndongo-Bidyogo, El Metro 336-7). The metro simultaneously represents a space where African migrant subjects stand out from an anonymous mass because of their blackness. It is within 
this space of hypervisibility and invisibility that the protagonist is murdered by a group of neo-Nazis. The metro in Ndongo-Bidyogo's novel can also be read as a 'nonplace' (non-lieu) according to Marc Augé (Arbeláez 1050-5; Chiodaroli 187-90): being a place of transit that the individual does not seize and where they stay anonymous and solitary, the metro station in Ndongo-Bidyogo's text represents the protagonist's situation of continuous transit and of non-arrival. Similarly, Ugarte (82) argues that the space of the metro evokes images of unfamiliarity and strangeness.

A central strategy of Ndongo's novel is to contrast the movement of some to the fixity of others. On his journey to Europe, Lambert meets many characters whose movements come to a standstill. At times, this standstill is the result of the character's demise, while sometimes the characters lack the necessary means to continue their journey. Just as the main character leaves behind his kin, the narration leaves behind many life stories that remain unfinished $(229-30 ; 257-61 ; 265-8)$. The potential of a literary text is that it can 'de-immobilize' or 're-mobilize' stories and carry voices across borders. El Metro's narrator unveils untold stories and their silencing. While dying, the protagonist imagines hearing his grandfather's voice saying, "y tu muerte no será una muerte anónima" (and your death will not be an anonymous death) (342). These words echo the end of chapter one (18) and, once again, emphasize the circularity of the narration. They demonstrate the potential of the literary text in subverting the anonymity of undocumented migration and challenging the solitude of nameless victims, offering "el consuelo de ser llorado[s]" (the comfort to be mourned) (219).

Furthermore, Ndongo-Bidyogo's novel strongly represents the dichotomy between 'male mobility' and 'female fixity,' highlighting African women's double marginalization. As María Lugones (742) theorizes, the modern/colonial gender system is based on a biologically motivated dimorphism and a patriarchal viewpoint that doubly oppresses non-Western women, for it establishes asymmetric power structures based on intersecting mechanisms of discrimination, specifically race and gender. Depicting a patriarchal African society in which women are consistently portrayed as submissive, unprivileged, or dependent on men, the novel reveals the female African subject as more vulnerable and less mobile than men (Celaya; Clarsen 96; Montuori).

Thus, while Lambert keeps moving in search of a better future, women are left behind. Twice, the protagonist impregnates a woman and then leaves: his childhood sweetheart, Anne Mengue, and his girlfriend in Yaoundé, Sylvie Anguesomo. As the novel illustrates, these women do not have the option to move on; they stay behind, negotiating a context in which they lack prospects and face marginalization as single mothers. Their only option is to agree to new dependencies, dependencies on men. As the protagonist derogatorily explains, after his departure, Sylvie seems to turn into "una buscablancos" (a looking-for-white) to find a new breadwinner (NdongoBidyogo, El Metro 310). And before the protagonist succeeds in borrowing a dowry to marry her, Sylvie's parents begin to coerce her into an arranged marriage (329). 
Similarly, Anne's options are limited. Keen to rebel against "a gendered system that subordinates females" (Montuori 55), her rebellion finds its expression in the narrative structure as well, a structure that, several times, repeats the expression "estaba harta de" (she was fed up with) (Ndongo-Bidyogo, El Metro 205). Anne dreams of a better life for herself and her daughter, one free from male oppression (205). Yet, she does not dispose of the necessary means to pursue this dream. Instead, "el sueño se convirtió en pesadilla" (the dream turned into a nightmare) (207), as she ends up in the city of Douala as a sex worker oppressed by the pimp Marcel Nosécuantos (206).

Anne's fate reminds us of other female characters in the novel, such as the Equatoguinean migrant Nene Paula who, during and after migration, also suffers from abuse, isolation, and dependency on men (Ndongo-Bidyogo, El metro 146-8; Montuori 50-2). Furthermore, on his journey to Europe, Lambert stands in line at a beach together with other undocumented migrants who are inclined to make use of the services of some African women who engage in sex work as a means to secure their passage on a boat to the Canary Islands (251-2). This scene illustrates clearly assigned positions of power and powerlessness due to gender hierarchies that persist within migrant communities. Strikingly, these women are not offered a proper voice in the novel. Their fate is mediated by the protagonist's hegemonic male gaze, being one of those who take part in abusing these women's marginalized position by giving in to their own sexual cravings. Thus, the novel does not extend a position of subjectivity to these female characters, for, when they drown-with many others-in visual range of the 'promised land' of the Canary Islands (267), they directly turn from 'consumable bodies' to 'dead bodies.' Just as these women's stories are lost, Anne's traces vanish within the narration and both the main character and the reader can only speculate about her fate. A letter from home lets Lambert know that Anne has disappeared, and that people assume she succeeded in breaking free of her pimp and moving on towards Europe (328). Yet, keeping in mind the fates of the women who participate in sex work on the beach and then drown unmasks this hope as an illusion; the female African migrant's emancipation from male oppression during her journey, as well as the success of her journey, seem highly questionable.

Moreover, women's marginal position is once again reflected in the narrative structure. The novel is narrated by an omniscient heterodiegetic narrator who frequently adopts the protagonist's perspective, using the technique of the interior monologue to unfold the protagonist's thoughts (Ellison 165; Ugarte 84-5). Thus, the text is dominated by a male perspective that rarely offers insight into the grievances of female characters. There are few examples where Ndongo-Bidyogo's novel transcends this perspective. However, in chapter thirteen, the heterodiegetic narrator gives an account of Anne's path to sex work and, focalizing her perspective, reveals her personal thoughts on the oppression of women in African societies (205-6). Correspondingly, the narrative structure symbolically expresses female immobility: most of the time, 
women's stories are narrated extraneously, through a male-centered perspective and, even when a female voice rises for a very short moment within the narration, as in the example mentioned above, it immediately gets lost again in such a way that one never conclusively knows what really happened to Anne or her daughter.

\section{Conclusion}

Mba Abogo's and Ndongo-Bidyogo's texts emphasize the ambivalence of the mobilities paradigm in an era of transnational migration. They portray mobility and immobility as related to asymmetrical, hegemonic, and racialized power positions that constrict African migratory movements. Reading El Porteador de Marlow and El Metro through the lens of the mobilities paradigm demonstrates literature's potential in laying open the complexity of African migration to Europe by embracing questions of voluntary and involuntary mobilities and fixities. Both texts address questions of geographical, socioeconomic, and epistemic borders. Accordingly, they tackle the impenetrability not only of national territories but also of national communities and cultures which marginalize African migrants and create areas of restricted mobility. By disclosing this ambivalence, literature is able to make a valuable contribution to the current discussion on migration to Europe and transnational mobility as it unveils life stories that, otherwise, remain hidden, challenging what European societies think they know about those who arrive on European shores.

\section{Acknowledgements}

This research was funded by the Deutsche Forschungsgemeinschaft (DFG, German Research Foundation), project number 353492083.

\section{Notes}

1. Examples of testimonial and fictional texts that address the highly restricted mobilities of African migrants and the new forms of exclusion, injustice, and invisibility that often follow migration are Mamadou Dia's 3052-Persiguiendo un sueño (Pursuing a Dream), Patrick Lambal's and Jordi Tomàs i Guilera's El pescador que volia anar al país dels blancs (The Fisherman who Wanted to Travel to the Country of the Whites), Despin Tchoumke's Camaleón: la España del extranjero, as well as Franciso Zamora Loboch's El Caimán de Kaduna (The Caiman of Kaduna), Víctor Omgbá's Calella sen saída (Alley without an Exit), and Inongo Vi-Makomè's Nativas (Natives), to name but a few. At this point, one needs to emphasize that, although certain advertising efforts in the publishing industry and a predominant, biased vision of African immigrants as undocumented refugees might lead one to assume otherwise, migration as a phenomenon addressed by hispanophone authors covers a much broader spectrum of migratory experiences: it ranges from undocumented migration to political exile and stays in European countries for educational training or professional reasons and it embraces narratives that tackle life in the host society after migration as well (Brancato 11).

2. All translations of citations into English are mine.

\section{Works Cited}

Adey, Peter, et al., eds. The Routledge Handbook of Mobilities. Routledge, 2014.

Arbeláez, Olga. "Geografías imposibles: hogar y nación en las novelas de Donato Ndongo-Bidyogo." Revista 
Iberoamericana vol. 80, no. 248-9, 2014, pp. 1041-56. DOI: https://doi.org/10.5195/reviberoamer.2014.7216. Attia, Kader. Official Homepage. http://kaderattia.de/. Accessed 22 Feb. 2018.

Augé, Marc. Non-lieux. Introduction à une anthropologie de la surmodernité. Éd. du Seuil, 1992.

Berástegui Wood, Jorge. "El Porteador de Marlow / Canción negra sin color: La construcción de la hibridación en la novela hispanoafricana." De Guinea Ecuatorial a las literaturas hispanoafricanas. Eds. Landry-Wilfrid Miampika \& Patricia Arroyo. Verbum, 2010, pp. 93-106.

Borst, Julia. "'To Be Black in a White Country:' On the Ambivalence of the Diasporic Experience in César Mba Abogo's El Porteador de Marlow. Canción negra sin Color (2007)." Research in African Literatures vol. 28, no. 3, 2017, pp. 33-54. DOI: https://doi.org/10.2979/reseafrilite.48.3.06.

Brancato, Sabrina. Afro-Europe. Texts and Contexts. Trafo, 2009.

Celaya, Beatriz. "De victorias o derrotas. El metro, de Donato Ndongo-Bidyogo." Romance Quarterly vol. 57, 2010, pp. 142-57. https://doi.org/10.1080/08831150903504745.

Chiodaroli, Sara. “Metrópolis y espacios urbanos en los textos de la 'literatura de la inmigración' en España: El metro de Donato Ndongo-Bidyogo, Calella sen saída de Víctor Ombgá y Ciudad sonámbula de Lilián Pallares." Iberoromania vol. 73-4, no. 1, 2012, pp. 186-95. DOI: https://doi.org/10.1515/ibero-2011-0013.

Clarsen, Georgine. "Feminism and Gender." The Routledge Handbook of Mobilities. Eds. Peter Adey, et al. Routledge, 2014, pp. 94-102.

Cross, Hannah. Migrants, Borders and Global Capitalism: West African Labour Mobility and EU Borders. Routledge, 2013.

Ellison, Mahan. "Oikos and the 'Other:' Humanizing the Immigrant in Donto Ndongo's El metro." African Immigrants in Contemporary Spanish Texts: Crossing the Strait. Eds. Debra Faszer-McMahon \& Victoria L. Ketz. Ashgate, 2015, pp. 161-75.

Ferry, Allison \& Mimi Sheller. "Mobility Justice." What is Mobilities? vol. 8, no. 1, 2014, http://wi.mobilities. ca/mimi-sheller-mobility-justice/. Accessed 21 Feb. 2018.

Fortier, Anne M. "Migration Studies." The Routledge Handbook of Mobilities. Eds. Peter Adey, et al. Routledge, 2014, pp. 64-73.

Gorroño, Raúl. “La literatura tiene la función de ayudar a la transformación social.” El Día, 27 Sep. 2015. http://web.eldia.es/cultura/2015-09-27/19-literatura-tiene-funcion-ayudar-transformacion-social.htm. Accessed 1 Mar. 2016.

Khalili, Bouchra. Official Homepage. http://www.bouchrakhalili.com/the-constellations/. Accessed 24 Apr. 2019.

Koné, Ténon. Représentation du migrant noir africain dans El Metro de Donato Ndongo Bidyogo. Presses Académiques Francophones, 2015.

Kunz, Jan \& Mari Leinonen. "Europe without Borders. Rhetoric, Reality or Utopia?" Migration without Borders: Essays on the Free Movement of People. Eds. Antoine Pécoud \& Paul de Guchteneire. UNESCO, 2007, pp. 137-60.

López Rodríguez, Marta S. "Más allá del exilio. El Porteador de Marlow / Canción negra sin color de César Mba." De Guinea Ecuatorial a las literaturas hispanoafricanas. Eds. Antoine Pécoud \& Paul de Guchteneire Arroyo. Verbum, 2010, pp. 85-92.

Luckow, Dirk. "Vorwort / Foreword." Streamlines. Ozeane, Welthandel und Migration / Oceans, global Trade and Migration (Exhibition Catalog). Ed. Deichtorhallen Hamburg. Snoeck, 2015, pp. 7-11.

Lugones, María. "Toward a Decolonial Feminism." Hypatia vol. 25, no. 4, 2010, pp. 742-59. DOI: https:// doi.org/10.1111/j.1527-2001.2010.01137.x.

Mba Abogo, César A. El Porteador de Marlow. Canción negra sin color. Sial, 2007.

Mengue, Clarence. "Lectura del espacio en Los poderes de la tempestad de Donato Ndongo Bidyogo." Arizona Journal of Hispanic Cultural Studies vol. 8, 2004, pp. 185-95. DOI: https://doi.org/10.1353/hcs.2011.0349.

Miampika, Landry-Wilfrid, \& Patricia Arroyo, eds. De Guinea Ecuatorial a las literaturas hispanoafricanas. Verbum, 2010.

Montuori, Chad. "Representing Gender on the Move from Africa to Spain. Donato Ndongo's El metro." Black Women, Gender and Families vol. 5, no. 2, 2011, pp. 44-65. DOI: https://doi.org/10.5406/ blacwomegendfami.5.2.0044.

Ndongo-Bidyogo, Donato. El Metro. Assata, 2014.

. El Sueño y otros relatos, Ed. Inmaculada Díaz Narbona. Verbum, 2017.

Nicholson, Judith \& Mimi Sheller. "Race and Mobility—Introduction." Transfers: Interdisciplinary Journal of 
Mobility Studies vol. 6, no. 1, 2016, pp. 1-11. DOI: https://doi.org/10.3167/TRANS.2016.060102.

Ohnmacht, Timo, et al. "Mobilities and Inequality: Making Connections." Mobilities and Inequality. Eds. Timo Ohnmacht, et al. Ashgate, 2009, pp. 7-25.

Otabela Mewolo, Joseph-Désiré. Literatura rebelde desde el exilio: Donato Ndongo-Bidyogo. Ediciones del Orto, 2010.

Otabela Mewolo, Joseph-Désiré \& Sosthène O. Abena. Entre estética y compromiso. La obra de Donato NdongoBidyogo. U Nacional de Educación a Distancia, 2008.

Pécoud, Antoine \& Paul de Guchteneire, eds. Migration without Borders: Essays on the Free Movement of People. UNESCO, 2007.

Seiler, Cotton. "Racing Mobility, Excavating Modernity: A Comment." Transfers: Interdisciplinary Journal of Mobility Studies vol. 6, no. 1, 2016, pp. 98-102. DOI: https://doi.org/10.3167/TRANS.2016.060108.

Ugarte, Michael. Africans in Europe: The Culture of Exile and Emigration from Equatorial Guinea to Spain. U of Illinois P, 2010.

Urry, John. Mobilities. Polity, 2007.

Wright, Michelle. Becoming Black: Creating Identity in the African Diaspora. Duke U P, 2004. 